\title{
ЗНАЧЕННЯ ІНТРА- ТА ПІСЛЯОПЕРАЦІЙНИХ УСКЛАДНЕНЬ У ПРОГНОЗУВАННІ ВИХОДУ ХІРУРГІЧНОГО ЛІКУВАННЯ ПРОЛІФЕРАТИВНОЇ ДІАБЕТИЧНОÏ РЕТИНОПАТІЇ
}

\author{
С. О. Риков, А. М. Рубан, А. Ю. Зольнікова \\ Національна медична академія післядипломної освіти імені П.А. Шупика \\ У статті представлені результати визначення прогностичної цінності впливу інтраопераційних та післяопераційних \\ ускладнень як факторів ризику на результат хірургічного втручання у хворих з проліферативною діабетичною \\ ретинопатією.
}

Ключові слова: прогнозування результату, фактори ризику, вітректомія, проліферативна діабетична ретинопатія

\section{ЗНАЧЕНИЕ ИНТРА- И ПОСЛЕОПЕРАЦИОННЫХ ОСЛОЖНЕНИЙ В ПРОГНОЗИРОВАНИИ ИСХОДА ХИРУРГИЧЕСКОГО ЛЕЧЕНИЯ ПРОЛИФЕРАТИВНОЙ ДИАБЕТИЧЕСКОЙ РЕТИНОПАТИИ}

\author{
С. А. Рыков, А. Н. Рубан, А. Ю. Зольникова \\ Национальная медицинская академия последипломного образования \\ имени П.А. Шупика
}

\begin{abstract}
В статье представлены результаты определения прогностической ценности влияния фракторов риска (интраоперационных и послеоперационных осложнений) на результат хирургического лечения пациентов с диабетической пролиферативной ретинопатией.
\end{abstract}

Ключевые слова: прогнозирование результата, факторы риска, витреэктомия, пролиферативная диабетическая ретинопатия

\section{INTRA AND POST VITRECTOMY COMPLICATIONS AS PREDICTIVE CLINICAL FEATURES FOR SURGICAL TREATMENT OF PROLIFERATIVE DIABETIC RETINOPATHY}

\author{
S .O. Rykov, A. M. Ruban, A. Yu. Zolnikova \\ National Medical Academy of Post-Graduate Education by P. L.Shupyk
}

\footnotetext{
The article describes the results in detection some factors that may predict visual outcome after vitrectomy for proliferative diabetic retinopathy.
}

Key words: predictive factors, vitrectomy, proliferative diabetic retinopathy.

Вступ. Задня закрита вітректомія (33В) дозволяє стабілізувати проліферативний процес в задньому відрізку ока та покращити функціональний стан зорових функцій більшості пацієнтів з розвинутими стадіями проліферативної діабетичної ретинопатії (ПДР) [1]. Впровадження сучасних технологій: малоінвазивної бімануальної хірургії $23 \mathrm{G}$ та $25 \mathrm{G}$, ширококутових офтальмоскопічних систем (BIOM, OFFISS), мультипортової ілюмінації (Torpido light), перфторкарбонових рідин, силіконового масла забезпечило вітреоретинальному хірургу ефективну технічну підтрим() С. О. Риков, А. М. Рубан, А. Ю. Зольнікова ку в останні роки [2]. Стабілізація або покращення зору після вітректомії досягається у 67-86 \% хворих [3]. Разом з тим, існують реальні ризики інтраопераційних та післяопераційних ускладнень (ятрогений розрив сітківки, крововилив, відшарування сітківки, неоваскулярна глаукома), які можуть призвести до незадовільного функціонального результату хірургічного лікування [4].

Метою дослідження було визначення прогностичної чинності інтра- та післяопераційних ускладнень як факторів ризику для прогнозування перебігу 
та результату хірургічного лікування пацієнтів з проліферативною діабетичною ретинопатією.

Матеріали та методи: Проведено ретроспективне дослідження результатів 80 операцій (вітректомій) у неселективній когорті 80 пацієнтів (80 очей) з проліферативною діабетичною ретинопатією (ПДР) 3 метою визначити рівень інтра та післяопераційних ускладнень та оцінити їх прогностичне значення на кінцевий зір.

Загальну групу склали пацієнти з вітреальним крововиливом, тракційним або тракційно-регматогеним відшаруванням сітківки. До групи не увійшли: пацієнти 3 первинним регматогеним відшаруванням сітківки, увеїтами або травмою. Мінімальний термін спостереження становив 6 місяців.

Чоловіків було 45 (56,3\%), жінок - 35 (43,8 \%). В групу увійшли 53 (66,2\%) пацієнти з 1 типом цукрового діабету, 27 (33,8 \%) пацієнтів з 2 типом цукрового діабету, тривалість діабету $>15$ років відмічена у 74 (94,9\%) пацієнтів та $<15$ років у 6 (5,1\%). Вік пацієнтів становив від 17 до 71 років, серед яких 29 пацієнтів (36,3\%) були молодше 50 років, та 51 пацієнт $(63,7 \%)$ старше 50 років.

Пацієнтам проводились стандартні офтальмологічні обстеження: візометрія, біомікроскопія, офтальмоскопія, статична та динамічна периметрія, тонометрія, ультразвукове сканування (при неможливості огляду очного дна), флуоресцентна ангіографія (для визначення макулярної ішемії сітківки), оптична когерентна томографія (для діагностики макулярного набряку, розриву сітківки, вітреомакулярної тракції).

Операції виконувались одним хірургом (РАM) за методою 3-портової вітректомії (моно- або бімануальною технікою) з використанням різних калібрів інструментів 20/23/25G. Видалялось центральне склоподібне тіло, проводилось усунення передньо-задніх тракцій та максимально повне видалення фіброваскулярних мембран технікою деламінації, сегментації або висічення «єдиним блоком». При необхідності проводилась панретинальна ендолазеркоагуляція. Для візуалізації очного дна використовували ширококутову систему BIOM (Oculus, Germany) або OFFISS (Topcon, Japan). При необхідності проведення хірургічних маніпуляцій на макулярній ділянці сітківки нами використовувалися контактні лінзи (Dorc, Netherlands). В більшості випадків проводилась одночасна факоемульсифікація кришталика 3 імплантацією м'якої ІОЛ. Силіконова або газова тампонада проводилась за визначенням хірурга.

Було досліджено три групи клінічних ускладнень: інтраопераційні, ранні післяопераційні (<1 місяця) та пізні післяопераційні (від 1 місяця до 6 місяців), які можна розглядати як гіпотетичні фактори ризику незадовільного результату операції.

Обчислення прогностичної значимості ознак грунтувалося на критерії Стьюдента в модифікації Амосова зі співавторами і полягало в порівнянні частоти несприятливого результату у хворих при наявності досліджуваної ознаки з частотою несприятливого результату у всіх хворих, обстежених на даний показник. Для цього аналізували 60 видів ускладнень (12 - інтраопераційних; 23 види, які виникли в ранньому післяопераційному періоді, 25 видів, які відмічені в пізньому післяопераційному періоді)

\section{Результати та їх обговорення.}

Тридцять вісім (47\%) з 80 очей мали максимально кориговану гостроту зору (МКГЗ) < 0,1 на кінцевому огляді, що визначалось як незадовільний функціональний результат операції (несприятлива група), та 42 (52 \%) ока мали МКГЗ > 0,1 (сприятлива група).

На підставі аналізу 60 різноманітних інтра- та післяопераційних ускладнень було відібрано 27 найбільш значимих для прогнозування результату операції (таблиця 1).

Проведений аналіз засвідчив, що такі інтраопераційні ускладнення як профузний крововилив $(3,1$ бала), ятрогений розрив сітківки (3,8 бала) та пошкодження зорового нерва (2,3 бала) мають суттєвий негативний вплив на результат хірургічного лікування.

Разом $з$ тим, розрив капсульного мішка, неадекватний мідріаз, субретинальний крововилив, субретинальне попадання перфтордекаліну, макулярний розрив, пошкодження райдужки, ішемія сітківки, супрахоріоїдальне попадання іригаційного розчину та пошкодження кришталика не мали суттєвого негативного впливу на результат операції.

Аналізуючи отримані дані слід зазначити, що ятрогенні розриви сітківки є найбільш вагомим (прогностична вага дорівнює 3,8 ) ускладненням вітректомії у хворих на цукровий діабет. Це пояснюється як достатньо високим рівнем виникнення даної ознаки під час операції, так і тяжкими наслідками (розвитком відшарування сітківки). Отримані дані знаходять підтвердження в роботі Thompson, який, проаналізувавши 1007 випадків, прийшов до висновку, що виникнення під час операції ятрогенних розривів сітківки є фактором поганого прогнозу [5].

Поява профузних крововиливів (прогностична вага дорівнює 3,1) робить вкрай складним або навіть неможливим повне та безпечне видалення фіброваскулярних мембран, підвищує ризик появи ятрогенних розривів сітківки, ускладнює проведення реаплікації та 
Таблиця 1. Найбільш значущі фактори для прогнозування результату операції

\begin{tabular}{|c|c|c|c|c|c|c|c|}
\hline \multirow[b]{2}{*}{ Фактор ризику } & \multirow[b]{2}{*}{$\mathrm{N}$} & \multicolumn{4}{|c|}{ Частота несприят/ливого наслідку, } & & \multirow{2}{*}{$\begin{array}{c}\text { Значи- } \\
\text { мість у } \\
\text { балах }\end{array}$} \\
\hline & & $\begin{array}{c}\text { загальна } \\
\text { група }\end{array}$ & & $\begin{array}{c}\text { несприят } \\
\text { лива } \\
\text { група }\end{array}$ & & & \\
\hline \multicolumn{8}{|c|}{ Інтраопераційні ускладнення } \\
\hline Профузний крововилив & 80 & 26,3 & 4,9 & 55,3 & 8,1 & 38 & 3,1 \\
\hline Ятрогенний розрив сітківки & 80 & 50,0 & 5,6 & 81,6 & 6,3 & 38 & 3,8 \\
\hline Пошкодження зорового нерва & 79 & 21,5 & 4,6 & 43,2 & 8,1 & 37 & 2,3 \\
\hline \multicolumn{8}{|c|}{ Ранні післяопераційні ускладнення (до 1 міс.) } \\
\hline Преретинальний крововилив під силіконом & 80 & 52,5 & 5,6 & 76,3 & 6,9 & 38 & 2,7 \\
\hline Фібрин - синдром & 80 & 26,3 & 4,9 & 50,0 & 8,1 & 38 & 2,5 \\
\hline Передня ішемічна оптична нейропатія & 80 & 22,5 & 4,7 & 47,4 & 8,1 & 38 & 2,7 \\
\hline Атрофія зорового нерва & 80 & 33,8 & 5,3 & 71,1 & 7,4 & 38 & 4,1 \\
\hline Емульгація силікону & 80 & 20,0 & 4,5 & 42,1 & 8,0 & 38 & 2,4 \\
\hline Іридоцикліт & 80 & 31,3 & 5,2 & 65,8 & 7,7 & 38 & 3,7 \\
\hline \multicolumn{8}{|c|}{ Пізні післяопераційні ускладнення (3 міс.) } \\
\hline Підвищення внутрішньоочного тиску & 80 & 30,0 & 5,1 & 63,2 & 7,8 & 38 & 3,6 \\
\hline Тракційне відшарування сітківки & 80 & 18,8 & 4,4 & 39,5 & 7,9 & 38 & 2,3 \\
\hline Макулярний набряк & 80 & 27,5 & 5,0 & 50,0 & 8,1 & 38 & 2,4 \\
\hline Ішемічна макулопатія & 80 & 43,8 & 5,6 & 92,1 & 4,38 & 38 & 6,8 \\
\hline Епімакулярний фіброз & 80 & 35,0 & 5,3 & 68,4 & 7,5 & 38 & 3,6 \\
\hline Репроліферація & 80 & 27,5 & 5,0 & 57,9 & 8,0 & 38 & 3,2 \\
\hline Задні синехії & 80 & 17,5 & 4,3 & 36,8 & 7,8 & 38 & 2,2 \\
\hline Кератопатія & 80 & 15,0 & 4,0 & 31,6 & 7,5 & 38 & 2,0 \\
\hline Фіброз задньої капсули & 80 & 58,8 & 5,5 & 86,8 & 5,5 & 38 & 3,6 \\
\hline Неоваскуляризація сітківки & 80 & 22,5 & 4,7 & 47,4 & 8,1 & 38 & 2,7 \\
\hline Неоваскулярна глаукома & 80 & 17,5 & 4,3 & 36,8 & 7,8 & 38 & 2,2 \\
\hline Атрофія зорового нерва & 80 & 37,5 & 5,4 & 78,9 & 6,6 & 38 & 4,9 \\
\hline Емульгація силікону & 80 & 33,8 & 5,3 & 71,1 & 7,4 & 38 & 4,1 \\
\hline Іридоцикліт & 80 & 30,0 & 5,1 & 63,2 & 7,8 & 38 & 3,6 \\
\hline Регматогенне відшарування сітківки* & & & & & & & 4,5 \\
\hline $\begin{array}{l}\text { Передня гіалоїдна фіброваскулярна } \\
\text { проліферація* }\end{array}$ & & & & & & & 4,5 \\
\hline Ендофтальміт* & & & & & & & 4,5 \\
\hline Субатрофія ока* & & & & & & & 4,5 \\
\hline
\end{tabular}

ендолазеркоагуляції сітківки. Крім того, виникнення інтраопераційних крововиливів значно підвищує ризик розвитку фібринозного синдрому, вітреального крововиливу, репроліферації в післяопераційному періоді, що також може впливати на кінцевий результат [6].

Прогностична цінність ознаки «пошкодження зорового нерва» (прогностична вага - 2,3), пов'язана як 3 тяжкими наслідками (виникнення часткової або повної атрофії зорового нерва), так і з неефективністю їх консервативного лікування. В літературі ми не знайшли посилань на вивчення цієї ознаки як прогностичного фактора незадовільного результату операції, що потребує їі подальшого вивчення.

Серед ранніх післяопераційних ускладнень (до 1 міс.), які мають негативний вплив на результат операції, найбільш важливими виявилися: атрофія зорового нерва (4,1 бала), іридоцикліт (3,7 бала), передня ішемічна оптична нейропатія (2,7 бала), преретинальний крововилив під силіконом (2,7 бала), фібрин синдром (2,5 бала) та емульгація силікону (2,4 бала).

Виникнення в ранній післяопераційний період тракційного або регматогенного відшарування сітківки, передньої гіалоїдної проліферації, кератопатії, інтравітреального крововиливу, підвищення внутрішньоочного тиску, зниження внутрішньоочного тиску, макулярного набряку, субретинального крововиливу, репроліферації, помутніння кришталика, задніх синехій, фіброзу задньої капсули, неоваскуляризації сітківки, неоваскулярної глаукоми та субретинального силікону, за отриманими нами даними, не мали суттєвого негативного значення для прогнозу результату операції.

Аналіз прогностичної інформативності пізніх післяопераційних ускладнень показав, що такі фактори, як неоваскуляризація сітківки (2,7 бала), неоваскулярна 
глаукома (2,2 бала), атрофія зорового нерва (4,9 бала), емульгація силікону (4,1 бала), іридоцикліт (3,6 бала), тракційне відшарування сітківки (2,3 бала), задні синехії (4,1 бала), репроліферація (3,2 бала), макулярний набряк (2,4 бала), підвищення внутрішньоочного тиску (3,6 бала), кератопатія (2,0 бали), ішемічна макулопатія (6,8 бала), епімакулярний фіброз (3,6 бала), фіброз задньої капсули (3,6 бала) мають несприятливий вплив на результат операції.

Такі фактори, як інтравітреальний крововилив, передня гіалоїдна проліферація, зниження внутрішньоочного тиску, субретинальний крововилив, регматогенне відшарування сітківки, преретинальний крововилив під силіконом, помутніння кришталика, фіброз задньої капсули, субретинальний силікон не мали суттєвого негативного впливу на результат операції.

Необхідно зазначити, що більшість незадовільних результатів хірургічного лікування хворих з ПДР автори напряму пов'язують 3 поствітректомічними ускладненнями [7, 8]. Значна кількість визначених нами післяопераційних ускладнень, як факторів ризику у прогнозуванні виходу хірургічного лікування хворих на ПДР, узгоджується з літературними даними. До них насамперед належать: фібрин-синдром, неоваскуляризація сітківки, неоваскулярна глаукома, атрофія зорового нерва, іридоцикліт, тракційне відшарування сітківки. Так, за даними Б. Уогйоп [9], такі післяопераційні ускладнення, як рецидивуючий вітреальний крововилив, тракційне або комбіноване тракційно/регматогенне відшарування сітківки, неоваскуляризація райдужки та неоваскулярна глаукома можуть призвести до значної втрати зору.

Отримані нами результати свідчать про те, що найбільш важливими післяопераційними ускладненнями були ознаки «атрофія зорового нерва» та «ішемічна макулопатія». Це пов'язано як $з$ достатньо високим рівнем зустрічання даних ознак серед хворих на цукровий діабет в загальній групі, так і з тим, що атрофія зорового нерва та ішемічна макулопатія $\epsilon$ результатом інтегрованої дії багатьох інтраопераційних (фототоксична дія освітлювання, термічне пошкодження при ендодіатермії та лазерокоагуляції, механічна травма при дирекції мембран та гідростатичному гемостазі) та післяопераційних (прогресуюча втрата перфузіі) факторів. Отримані дані узгоджуються 3 результатами опублікованих раніше робіт, в яких автори відносять до післяопераційних факторів ризику значного погіршення зору оптичну або макулярну ішемію та атрофію [10].

Прогностична цінність ознаки «фібриноїдний синдром» пояснюється тим, що їі поява може потенційно призвести до глаукоми зіничного блока або, внаслідок контракції волокон фібрину, відшарування сітківки, рубеозу та неоваскулярної глаукоми [11]. Ризик-факторами фібринозного синдрому з відшаруванням сітківки, за даними літератури, є погано контрольований перебіг 1 типу цукрового діабету, попередня хірургія діабетичного відшарування сітківки, занадто травматична операція (проведення склерального пломбування, панретинальна лазерокоагуляція, кріоретинопексія, ленсектомія) [12]. Близько однієї третини очей 3 фібрин-синдромом добре піддаються лікуванню великими дозами місцевих та системних стероїдів.

Прогностична важливість ознаки «іридоцикліт» пояснюється патогенетично обумовленим впливом запалення на розвиток діабетичної мікроангіопатії, неоваскуляризації та проліферації. Отримані нами дані підтверджують результати Azzolini, який продемонстрував, що післяопераційний увеїт є важливим фактором ризику прогресування діабетичної мікроангіопатії [13].

Важливість ознаки «преретинальний крововилив» пов'язана з тим, що повільне розсмоктування преретинального крововиливу в післяопераційному періоді призводить до суттєвого збільшення термінів зорової реабілітації пацієнтів, може стимулювати розвиток тракційної деформації сітківки, їі відшарування та значно знижує анатомічні та функціональні результати хірургічного лікування.

Значимість ознаки «емульгація силікону» в прогнозуванні негативного результату операції пов'язана 3 тим, що ii наявність викликає цілу низку патологічних процесів (кератопатія, глаукома, атрофія зорового нерва, іридоцикліт, макулярний набряк тощо), спроможних призвести до загибелі ока [14]. Частота емульгації силікону залежить від тривалості тампонади, в'язкості силікону, супутніх факторів (крововилив, запалення, зміна рН, енергія від факоемульсифікатора) [15]. Заходи профілактики емульгації силікону, як і оптимальні терміни виведення силікону, не розроблені та потребують подальшого вивчення.

Слід відмітити отриманий нами суттєвий негативний вплив на результат операції ознаки «підвищення внутрішньоочного тиску», що підтверджується літературними даними і пояснюється як поширеністю використання силіконових тампонад при проведенні вітректомії, так і прогресуванням неоваскуляризації райдужки та кута передньої камери, що призводить до розвитку глаукоми.

У зв'язку з невеликою кількістю хворих, які мали в післяопераційному періоді такі важливі ускладнення, як регматогенне відшарування сітківки, передня гіалоїдна фіброваскулярна проліферація, ендоф- 
тальміт, субатрофія ока низка ознак, наведених у таблиці, також траплялася рідко (їх позначено зірочкою). Однак їх клінічна важливість не викликає сумніву, тому значущість їх у балах визначали за допомогою евристичного оцінювання. Експертна оцінка цих ознак була високою: 4,5 бала, тому що, згідно 3 нашим клінічним досвідом та сучасними даними літератури [16,17], поява цих ускладнень може призвести до загибелі ока.

Отже, можна вважати, що наведені в роботі результати будуть сприяти оптимізації прийняття рішення при виборі тактики хірургічного лікування хворих на проліферативну діабетичну ретинопатію. Подальше вивчення факторів ризику та розробка заходів профілактики виникнення ускладнень дозволять підвищити ефективність хірургічного лікування та реабілітації цієї категорії хворих.

Висновки: 1. Провідними факторами в оцінювані ризику незадовільного результату вітректомії у хво-

\section{Література}

1. Риков С. О. Сліпота та слабкозорість. Шляхи профілактики в Україні / С. О. Риков. -Київ, 2011. - 268 с.

2. Steinmetz R. L.Vitrectomy for diabetic tration retinal detachment using the multiport illumination system / R. L. Steinmetz, S. Grizzard, M. E. Hammer // Ophthalmology. - 2002. - Vol.109. - P. 2303-2307.

3. Recent outcomes of vitreous surgery for diabetic retinopathy / H. Oda, K. Konno, K. Mitsui [et al.]// Nippon Ganka Gakkai Zasshi. - 2005. -Vol. 109. - P. 603-612.

4. Ishida M. Long-term results of vitrectomy for complications of proliferative diabetic retinopathy/M. Ishida, S. Takeuchi // Jpn. J. Ophthalmol. - 2002. Vol. 46. - P. 117-122.

5. Thompson J. T. Prognostic indicators of success and failure in vitrectomy for diabetic retinopathy/ J. T. Thompson, C. L. Auer, S. de Bustros [et al.]// Ophthalmology. - 1986/ - Vol. 93. - P. 290-295.

6. Complications of vitreous surgery for diabetic retinopathy. I. Intraoperative complications/ R. T. Oyakawa, A. P. Schachat, R. G. Michels, T. A. Rice// Ophthalmology. - 1983. - Vol. 9.- P. 517.

7. Complications of vitreous surgery for diabetic retinopathy. II. Postoperative complications /R. T. Oyakawa, A. P. Schachat, R. G. Michels, T. A. Rice// Ophthalmology. - 1983. - Vol. 90. P. 522-530.

8. Complications of vitrectomy for non-clearing vitreous haemorrhage in diabetic patients/W. E.Benson, G. Brown, W. Tasman, J. A. McNamara // Ophthalmic. Surg. - 1988. - Vol. 19. P. 862- 864 .

9. Predictive clinical features and outcomes of vitrectomy for рих на проліферативну діабетичну ретинопатію серед інтраопераційних ускладнень є: поява ятрогенних розривів сітківки, профузного крововиливу та пошкодження зорового нерва.

2. Провідними післяопераційними факторами в оцінюванні ризику результату вітректомії $є$ ішемічна макулопатія, атрофія зорового нерва, фібрин-синдром, передня ішемічна оптична нейропатія, емульгація силікону, преретинальний крововилив під силіконом, неоваскуляризація сітківки, неоваскулярна глаукома, тракційне відшарування сітківки, репроліферація, макулярний набряк, підвищення внутрішньоочного тиску, кератопатія, епімакулярний фіброз.

Аналіз факторів ризику надає можливість створення схеми визначення ризику клінічного перебігу та результатів хірургічного лікування хворих з проліферативною діабетичною ретинопатією, що дозволить кількісно оцінити стан хворих і забезпечити коректне прогнозування результатів лікування.

proliferative diabetic retinopathy/ D. Yorston, L. Wickham, S. Benson [et al.]// Br. J. Ophthalmol. - 2008. - Vol. 92. - P. 365 368

10. Visual outcome after vitrectomy for diabetic retinopathy. A five-year followup/ M. Nakazawa, Y Kimizuka, T. Watabe [et al.]//Acta. Ophthalmol. (Copenh). -1993. - Vol. 71. - P. 219-223. 11. Sebestyen J. G. Fibrinoid syndrome: a severe complicationof vitrectomy surgery in diabetics/ J. G. Sebestyen// Ann. Ophthalmol. - 1982. - Vol. 14. - P. 853-856.

12. Ho T. Vitrectomy in the management of diabetic eye disease/ T. Ho, W. E. Smiddy, H. W. Flynn// Surv. Ophthalmol. - 1992. Vol. 37. - P. 190-202.

13. Influence of silicone oil on iris microangiopathy in diabetic vitrectimized eyes/C. Azzolini, R. Brancato, F. I. Camesasca [et al.]// Ophthalmology. - 1993. - Vol. 100. - P. 1152-1159.

14. Chemical stability of silicone oil in the human eye after prolonged clinical use/ A. Lakits, T. Nennadal, C. Scholda [et al.]// Ophthalmology. - 1999. - Vol. 106. - P. 1091-1100.

15. Francis J. H. Mechanical energy from intraocular instruments cause emulsification of silicone oil/ J. H. Francis, P. A. Latkany, J. L. Rosenthal // Br. J. Ophthalmol. - 2007. - Vol. 91. - P. 818-821.

16. Incidence of endophthalmitis after 20- and 25-gauge vitrectomy causes and prevention/ H. Shimada, H. Nakashizuka, T. Hattori, [et al.] // Ophthalmology. - 2008. Vol. 115. - P. 2215-2220.

17. Lewis $\mathrm{H}$. Anterior hyaloidal fibrovascular proliferation after diabetic vitrectomy/H. Lewis, G. W. Abrams, G. A. Williams // Am. J. Ophthalmol. - 1987. - Vol. 104. - P. 607-613. 